\title{
Bioaccumulation dynamics and gene regulation in a freshwater bivalve after aqueous and dietary exposures to gold nanoparticles and ionic gold
}

\author{
Adeline Arini $^{1} \cdot$ Fabien Pierron $^{1} \cdot$ Stéphane Mornet $^{2} \cdot$ Magalie Baudrimont $^{1}$
}

\begin{abstract}
Gold nanoparticles (AuNPs) are being developed and produced for a wide variety of industrial and biomedical applications, which raises the concern about their release and potential effects in the environment. In this study, we aim to assess the effects of PEGylated AuNPs and ionic gold on the freshwater bivalve Corbicula fluminea. As NP bioavailability is conditioned by many factors of variability, we focused on the determination of biodynamic parameters which control AuNP uptake and elimination in bivalves. Three experiments were conducted: (1) a waterborne exposure (0-24 mg/L for AuNPs and 0-12 mg/L for ionic gold), (2) a dietborne exposure (0-48 mg/L for AuNPs and 0-24 mg/L for ionic gold), and (3) an elimination phase (after waterborne exposure to $12 \mathrm{mg} / \mathrm{L}$ for AuNPs and $24 \mathrm{mg} / \mathrm{L}$ for ionic gold), to calculate rate constants for uptake from water(kuw), from food $(k u f)$, and for the physiological elimination $(k e)$ for $\mathrm{AuNPs}$ and $\mathrm{AuCl}(\mathrm{OH})_{3}{ }^{-}$. Jointly, the relative expression of several genes was investigated in the hemolymph cells to relate AuNPs and gold ion exposures to detoxification, oxidative stress, immune, and apoptosis responses in C. fluminea. Results show that kuw and kuf were around 10 and 30 times higher for AuNPs compared to $\mathrm{AuCl}(\mathrm{OH})_{3}{ }^{-}$, respectively. The $k e$ was also faster in clams exposed to AuNPs meaning that they also had greater excretion capacities in comparison to gold ions. Water seems to be the main exposure pathway for C. fluminea according to kuw and kuf values for $\mathrm{AuNPs}$ and $\mathrm{AuCl}(\mathrm{OH})_{3}{ }^{-}(\mathrm{kuw}=0.28$ and 0.03 , $\mathrm{kuf}=0.009$ and 0.001 , respectively). The gene analyses pointed out important responses against oxidative stress, strong activations of genes of the immunity, and apoptosis after the waterborne exposure to AuNPs and to a lesser extent after exposure to gold ions. Very few responses were observed after the dietary exposure to both forms of gold, probably due to valve closure in response to contamination. While some studies suggest that the toxicity of nanoparticles may come from the release of metal ions, our results showed that the AuNPs we used were very stable (less than 1\% of ion release) and generated more effects at the gene level than ionic gold. Therefore these results highlight the strong potential of toxicity of AuNPs compared to ionic gold and raise new concerns about the toxicity inherent to NPs in the environment.
\end{abstract}

Keywords Gold nanoparticles · Toxicity $\cdot$ Biodynamic $\cdot$ Rate constants $\cdot$ Bivalves $\cdot$ Corbicula fluminea $\cdot$ Gene expression

Adeline Arini

adeline.arini@u-bordeaux.fr

1 UMR EPOC 5805, Place du Dr Peyneau, Université de Bordeaux CNRS, 33120 Arcachon, France

2 UMR 5026, Institut de Chimie de la Matière Condensée de Bordeaux Université de Bordeaux-CNRS, 33600 Pessac, France

\section{Introduction}

Due to their unique properties showing great potentials for cell imaging, targeted drug delivery, and therapeutics, engineered gold nanoparticles (AuNPs) are being developed and produced for a wide variety of industrial and biomedical applications (Daniel and Astruc 2004; Giljohann et al. 2010). As application fields continue to develop, unintended releases will most likely account for nanomaterial inputs to natural environments. At the nanometric scale, NPs acquire novel physicochemical properties that may influence bioavailability, which raises concerns about their toxicity to wildlife (Nel et al. 2006). 
Indeed, the chemical toxicity of a xenobiotic in aquatic organisms is mainly governed by its bioavailability, in other terms by its accumulation pathways into the organisms, including water and food (Luoma and Rainbow 2005). Therefore, it is crucial to understand the accumulation pathways of NPs in aquatic organisms in order to understand and predict their toxicity.

Biokinetic models have been developed in the 1990s to provide a realistic way to separate the exposure by directly comparing metal fluxes from water and food (Wang 2013). The use of such models helps delineate the exposure pathways and compare the preferential entry route for metal fluxes into organisms (Wang 2013). Such studies have already been conducted in gastropods for example (Croteau et al. 2011, 2014) but not yet in bivalves where we expect the aqueous route to be predominant for the metal flux, based on their filtration activity. Coating agents are often used to stabilize NP, such as citrate, polyvinylpyrrolidone (PVP), and polyethylene glycol (PEG) (García-Negrete et al. 2013; Renault et al. 2008; Teles et al. 2017; Volland et al. 2015).

But it has been demonstrated that the coating could influence NP toxicity by modifying its bioavailability and the release of metal ions from the NP which can have more toxic properties than the NP itself (Katsumiti et al. 2015; Navarro et al. 2008). The coating can also be designed to facilitate NP transport and diffusion through cells. Once internalized, massive delivery of ions released from the NPs can occur into cells (Trojan horse mechanisms (Luoma 2008)), which can even be more hazardous for wildlife. From this statement, it is difficult to discriminate the effect from NPs and their ionic counterparts. Modification of NP surfaces with PEG has become a popular method to gain in stability (Paciotti et al. 2004) and reduce nonspecific interactions with serum proteins (Dai et al. 2014), which avoid them from being recognized and cleared by the immune system (Pelaz et al. 2015). If silver, titane, and other metal nanoparticles are well studied, still few studies refer to toxic effects of gold nanoparticles (AuNPs) in aquatic organisms, and even less on bivalves (García-Negrete et al. 2013; Hull et al. 2011; Joubert et al. 2013; Renault et al. 2008; Volland et al. 2015). Among them, Renault et al. (2008) showed that amine-coated AuNP particles could cross the epithelia of the digestive tract and gills of Corbicula fluminea after trophic exposure and upregulate the metallothionein expression as well as antioxidant enzyme encoding genes. Similar results were obtained from waterborne exposures by Tedesco et al. (2008) who reported an oxidative stress in the digestive gland of Mytilus edulis exposed to environmentally relevant concentrations $(0.75 \mu \mathrm{g} / \mathrm{L})$ of citrateAuNPs. Volland et al. (2015) also showed that $0.75 \mu \mathrm{g} /$ Lof citrate-AuNPs could induce an oxidative stress and inflammatory gene response in Ruditapes philippinarum, but it was not concomitant with an oxidative damage. Therefore, the authors could not conclude that AuNPs were toxic for bivalves at these concentrations. Since very few studies use PEG coating for the assessment of AuNP toxicity, it makes difficult to actually link AuNPs to related effects, without misinterpreting data by the presence of potentially released gold ions.

In this study, we aim to assess the effects of PEGylated AuNPs on bivalves, starting from the premise that if the NP stability is increased by using PEG, we might expect to target more accurately NP accumulation and effects, which may differ from their ionic counterpart. We chose to use Corbicula fluminea, a commonly used freshwater clam, which has demonstrated its relevance as a biological model in different environmental studies, including gold exposures (Arini et al. 2011; Renault et al. 2008). As NP bioavaibility can vary with chemical, abiotic, and behavioral parameters, such as NP coating, pH, and reduced feeding activities (Buffet et al. 2013; Diegoli et al. 2008; Teles et al. 2017), we focused on the biodynamic parameters that control AuNP uptake and elimination in bivalves. Three experimentations were conducted: (1) a waterborne exposure, (2) a dietborne exposure, and (3) an elimination phase, to calculate constant rates of water accumulation, diet accumulation, and elimination for PEG-AuNPs and their ionic counterpart $\mathrm{AuCl}(\mathrm{OH})_{3}{ }^{-}$. Jointly, the relative expression of several genes were investigated by quantitative PCR (qPCR) in hemocytes to relate AuNPs and gold ion exposures to detoxification, oxidative stress, immune, and apoptosis responses in C. fluminea in order to better understand the potential toxicity of AuNPs.

\section{Methods}

\section{Gold nanoparticle synthesis}

Gold nanoparticles (AuNPs) were synthesized at the Institute of Chimie de la Matière Condensée de Bordeaux (ICBM), by a citrate reduction method, optimized from the Turkevich method (Kimling et al. 2006). To see the detailed process, refer to Renault et al. (2008). Briefly, pure gold powder (KAuCl4 at $99,995 \%$ ) was dissolved into $825 \mathrm{~mL}$ of ultra pure water (MilliQ) and boiled at $100{ }^{\circ} \mathrm{C}$. The reduction of auric salts occurs upon addition of a sodium citrate dihydrate solution forming spherical nanoparticles of $10 \mathrm{~nm}$ diameter, with a highly monodisperse size distribution, at a concentration of 9.9 $10^{16}$ particles per gram which corresponds to $2.51 \mathrm{~g} \mathrm{~L}^{-1}$. To optimize AuNP stability and avoid aggregation, nanoparticles were coated with polyethylene glycol (PEG), linked by thiol groups (-SH). Amine groups were added to confer a positive charge to the AuNPs. 


\section{Experimental organisms}

Scenedesmus subspicatus is a freshwater green algae belonging to the Chlorophycea family and widely used in ecotoxicological tests.

Corbicula fluminea is a freshwater clam, originated from Japan which was introduced in Europe in the 80s. This Asiatic clam lives buried in the superficial sediment layers but remains in direct contact with the water column on which it depends for its respiratory and nutritional filtration activities which makes $C$. fluminea a good bioindicator for ecotoxicological tests.

\section{Waterborne uptake experiment}

A batch of $C$. fluminea was collected in the Isle River (SouthWest France), where this species freely thrives in an uncontaminated environment. Clams were placed into a 20-L tank and acclimated and fed in clean water for a week before starting the experiment. Afterwards, 60 clams were transferred into six individual experimental units ( 10 clams per unit) filled with $2 \mathrm{~L}$ of moderately hard water (MOD: $1.14 \mathrm{mM} \mathrm{NaHCO}_{3}$; $\left.0.44 \mathrm{mM} \mathrm{CaSO}_{4} ; 0.50 \mathrm{mM} \mathrm{MgSO}_{4} ; 0.11 \mathrm{mM} \mathrm{HCl}\right)$. Aeration was continuously provided by a diffuser connected to an air pump and the temperature was maintained at $15^{\circ} \mathrm{C}$ by a cooler circuit. Artificial light was provided by 4 neons (photoperiod $12 \mathrm{~h}: 12$ h). Experimental units were spiked with different concentrations of either AuNPs $(0 ; 0.5 ; 1 ; 5 ; 12$ and $24 \mathrm{mg} /$ L) for $24 \mathrm{~h}$, or a gold standard solution $\left(\mathrm{H}\left(\mathrm{AuCl}_{4}\right) 3 \mathrm{H}_{2} \mathrm{O}\right.$, Sigma): $0 ; 0.1 ; 0.5 ; 1 ; 5$ and $12 \mathrm{mg} / \mathrm{L}$ ) for $3 \mathrm{~h}$. These concentrations were chosen based on the DL50 of $48 \mathrm{mg} \mathrm{AuNP/L}$ measured for Scenedesmus subspicatus, according to a previous study (Renault et al. 2008).

Studies have shown that the behavior and ecotoxicity of gold depend on conditions, such as the $\mathrm{pH}$ level. When $\mathrm{pH}>6$, like in our experimental units, the most numerous ions are $\mathrm{AuCl}(\mathrm{OH})_{3}{ }^{-}$(Diegoli et al. 2008), which represents the most toxic $\mathrm{Au}$ ions in aquatic organisms (LaprestaFernández et al. 2012). Assuming the fact that they are the most numerous ones, gold ions will be noted as $\mathrm{AuCl}(\mathrm{OH})_{3}{ }^{-}$ in the paper. Water samples were collected at the beginning and at the end of the experiment $(2 \mathrm{ml} ; n=3)$ and acidified with aqua regia (1:4 volumes of $\mathrm{HNO}_{3}$ and 3:4 volumes of $\mathrm{HCl} ; 10 \%$ final concentration). Clams were not fed during the exposure to avoid metal absorption onto algae and prevent from having an additional exposure via the trophic route.

\section{Dietborne uptake experiment}

Freshwater green algae Scenesdesmus subspicatus were cultured in the laboratory. Before use, they were centrifuged (3 min at $3500 \mathrm{rpm}$ ), and the pellet was gently resuspended in MOD to get a final concentration of $32.10^{6}$ cells $/ \mathrm{mL}$, corresponding to a DO of 0.36 at $750 \mathrm{~nm}$. This concentration was chosen according to previous tests to provide enough food supply without being in excess and limit pseudofeces production. Experimental vials of $100 \mathrm{~mL}$ were filled with the algal suspension and spiked with either AuNPs $(0 ; 5 ; 12$; 24 ; and $48 \mathrm{mg} / \mathrm{L}$ ) for $24 \mathrm{~h}$ or a gold standard solution $\left(\mathrm{H}\left(\mathrm{AuCl}_{4}\right) 3 \mathrm{H}_{2} \mathrm{O}: 0 ; 1 ; 5 ; 12\right.$ and $\left.24 \mathrm{mg} / \mathrm{L}\right)$ for $4 \mathrm{~h}$ under agitation. These concentrations were chosen to be in the range of Scenedesmus subspicatus' DL50 (48 mg/L). After this while, 8 clams were added per vial of $100 \mathrm{~mL}$ and exposed for $4 \mathrm{~h}$ to contaminated algae. Water was gently mixed every hour during clam exposure. Water samples were collected at the beginning of algae exposure, as well as at the beginning and at the end of clam exposure $(5 \mathrm{ml} ; n=3)$ and filtered (hydrophilic polypropylene membranes, $25 \mathrm{~mm}, 0.45 \mu \mathrm{m}$ pore size). Filters were dried in the oven at $45{ }^{\circ} \mathrm{C}$ for $24 \mathrm{~h}$ before being mineralized for $3 \mathrm{~h}$ at $100{ }^{\circ} \mathrm{C} \mathrm{h}$ (hot block CAL 3300, Environmental Express, USA) with $3 \mathrm{~mL}$ of aqua regia (1:4 volumes of $\mathrm{HNO} 3$ and 3:4 volumes of $\mathrm{HCl}$ ). Digestates were then diluted up to $18 \mathrm{ml}$ with ultrapure water (Milli-Q, Bedford, MA, USA). The filtrate was also collected to check for the residual gold concentration in the water compartment. Analyses showed that gold left in the water compartment was around 250 times less than the initial concentrations, which means that the great majority of gold was fixed on algae. At the end of the 4-h exposure, clams were taken out of the vials, rinsed and placed in open individual vials, themselves placed for $48 \mathrm{~h}$ into $12 \mathrm{~L}$ tanks filled with uncontaminated MOD, with aeration, a temperature of $15{ }^{\circ} \mathrm{C}$ and light cycles (12 h:12 h). This installation was made to allow feces collection from each individual. Clams were fed twice a day with Scenesdesmus subspicatus $\left(32.10^{6}\right.$ cells $\left./ \mathrm{mL}\right)$. Two times a day, individual vials were removed from tanks in order to collect clam feces. Feces samples were put in the oven at $45^{\circ} \mathrm{C}$ until water had completely evaporated. Then, they were digested with $0.2 \mathrm{~mL}$ aqua regia (1:4 volumes of $\mathrm{HNO}_{3}$ and $3: 4$ volumes of $\mathrm{HCl} ; 10 \%$ final concentration) during $48 \mathrm{~h}$ at room temperature and then diluted with $1.8 \mathrm{~mL}$ of ultrapure water. Clams were sacrificed after puncture of the hemolymph to collect the whole body and were mineralized with $3 \mathrm{~mL}$ of aqua regia (1:4 volumes of $\mathrm{HNO}_{3}$ and 3:4 volumes of $\mathrm{HCl}$; $10 \%$ final concentration) at $100{ }^{\circ} \mathrm{C}$ for $3 \mathrm{~h}$. Digestates were then diluted up to $18 \mathrm{ml}$ with ultrapure water and stored at $4{ }^{\circ} \mathrm{C}$ until analysis.

\section{Elimination experiment}

Around 80 clams were placed into a 40 -L tank $24 \mathrm{~h}$ before the start of the experiment. They were fed $2 \mathrm{~h}$ before being exposed. Then, they were exposed for $48 \mathrm{~h}$ to $24 \mathrm{mg} / \mathrm{L}$ of AuNPs or $12 \mathrm{mg} / \mathrm{L}$ of $\mathrm{H}\left(\mathrm{AuCl}_{4}\right) 3 \mathrm{H}_{2} \mathrm{O}$, to get similar exposure conditions as for the waterborne uptake experiment. After $48 \mathrm{~h}$, they were transferred into uncontaminated MOD (40 L) for 
28 days. Aeration was continuously provided by a diffuser connected to an air pump, and the temperature was maintained at $15^{\circ} \mathrm{C}$ by a cooler circuit. Artificial light was provided by 4 neons (photoperiod 12 h:12 h). Clams were fed every 2 days with suspensions of Scenesdesmus subspicatus. Water was changed every day for the first week then every 3 days to avoid re-uptake of gold from water. After 1 day, the gold concentration was of $0.5 \mathrm{mg} / \mathrm{L}$ and $0.3 \mathrm{mg} / \mathrm{L}$ for AuNPs and $\mathrm{H}\left(\mathrm{AuCl}_{4}\right) 3 \mathrm{H}_{2} \mathrm{O}$ respectively, and decreased strongly in the next days, down to values of 0.02 and $0.07 \mathrm{mg} / \mathrm{L}$ respectively at the end of the experiments. After 1, 2, 3, 5, 7, 10, 14, 21, and 28 days, 8 clams were sampled and sacrificed to measure gold depuration. Whole bodies were mineralized with aqua regia as described above. Control $C$. fluminea, unexposed to gold, were maintained under the same conditions and collected at each sampling time. Water samples ( $2 \mathrm{~mL}, n=3)$ were collected at each sampling time to check for gold release from the clams.

\section{Biodynamic model and rate constants}

Each gold sample was analyzed by atomic absorption spectrometry 240Z AA (Agilent Technologies). The validity of the method was periodically checked with a laboratory-certified reference material (CRM) made from gold-exposed Corbicula fluminea (averaged concentrations of $39.66 \pm 2.15 \mu \mathrm{g} / \mathrm{g}$, recovery of $101 \pm 1 \%(n=26))$.

The aforementioned experiments were used to calculate different rate constants that were integrated into the biodynamic model. Metal concentration in aquatic organisms $\left([\mathrm{M}]_{\mathrm{org}}, \mu \mathrm{mol} \mathrm{g}^{-1}\right.$ ) follows Eq. 1:

$[\mathrm{M}]_{\mathrm{org}}=k u w \times[\mathrm{M}]_{\mathrm{water}}+k u f \times[\mathrm{M}]_{\mathrm{food}}-k g \times[\mathrm{M}]_{\mathrm{org}}-k e \times[\mathrm{M}]_{\mathrm{org}}$

Metal influx from solution varies as a function of the metal uptake rate constant from water $\left(k u w, \mathrm{~L} \mathrm{~g}^{-1} \mathrm{~d}^{-1}\right)$, and the metal concentration in water $\left([\mathrm{M}]_{\mathrm{water}}, \mu \mathrm{mol} \mathrm{L}{ }^{-1}\right)$. Metal influx from food varies as a function of the metal uptake rate constant from food ( $k u f, \mathrm{~g} \mathrm{~g}^{-1} \mathrm{day}^{-1}$ ), and the metal concentration in food $\left([\mathrm{M}]_{\text {food }}, \mu \mathrm{mol} \mathrm{g}^{-1}\right)$. Metal influx is also a function of body growth dilution $\left(\mathrm{kg}\right.$, day $\left.{ }^{-1}\right)$, and elimination $\left(k e\right.$, day $\left.{ }^{-1}\right)$.

$K u f$ is also expressed as a function of food ingestion rate (IR, $\mathrm{g} \mathrm{g}^{-1}$ day $^{-1}$, Eq. 2) and the assimilation efficiency (AE, $\%$, Eq. 3), both depending on body metal burden and feces metal burden (Eq. 4):

$$
\begin{aligned}
\mathrm{IR} & =\frac{M_{\text {org }}+M_{\text {faeces }}}{[M]_{\text {food }} \times W_{\text {org }} \times T} \\
\mathrm{AE} & =\frac{M_{\text {org }}}{M_{\text {org }}+M_{\text {faeces }}} \times 100 \\
K u f & =\mathrm{IR} \times \mathrm{AE}
\end{aligned}
$$

where $M_{\text {org }}(\mu \mathrm{g})$ is the metal burden into organism after depuration, $M_{\text {feces }}$ (ng) is the metal burden into feces during depuration, $[M]_{\text {food }}(\mu \mathrm{g} / \mathrm{g})$ is the metal concentration in food, $W_{\text {org }}(\mu \mathrm{g})$ the dry weight of the organism and $T$ the time of elimination.

Metal influx in aquatic organisms (Eq. 5) can also vary with the number of transport sites $\left(\mathrm{B}_{\max }, \mu \mathrm{mol} \mathrm{g}^{-1}\right)$ and the affinity of transport sites for metal $\left(\mathrm{K}_{\mathrm{d}}, \mu \mathrm{mol} \mathrm{L} \mathrm{L}^{-1}\right.$ or $\mu \mathrm{mol}$ $\left.\mathrm{g}^{-1}\right)$, both depending on the metal exposure $\left([\mathrm{M}]_{\text {expo }}, \mu \mathrm{mol}\right.$ $\mathrm{L}^{-1}$ or $\mu \mathrm{mol} \mathrm{g}{ }^{-1}$ ).

Influx $_{\text {org }}=\frac{B_{\max } \times[M]_{\text {expo }}}{K_{d}+[M]_{\text {expo }}}$

\section{Differential gene expression}

Hemocytes were sampled with a puncture in the adductor muscle of $C$. fluminea since they are responsible for the immune defense of mollusks (Cajaraville and Pal 1995). Two samples were pooled per condition to get sufficient quantities for RNA extractions and stored in RNA later at $-80^{\circ} \mathrm{C}$ before use. Four replicates were analyzed per time and condition.

The total mRNA extraction was carried out with the SV Total RNA Isolation System (Promega), according to the manufacturer's instructions. The concentration of extracted RNA was measured with a microplate spectrometer (BioTek EPOCH) and a Take3 plate to estimate the purity of nucleic acids by comparing the ratio between values measured at 260 and $280 \mathrm{~nm}$ (purity is ensured if result is over 2). All RNA samples had a ratio over 2 . The RNA samples were diluted to have the same concentration in all samples before performing the reverse transcription (RT). A concentration of $30 \mathrm{ng} / \mu \mathrm{L}$ of RNA was used for the RT, using the GoScript Revers Transcription System (Promega), according to the manufacturer's instructions. RNA samples were incubated in an Eppendorf Mastercycler to synthetize cDNA after the reagents addition. cDNA samples were kept at $-20{ }^{\circ} \mathrm{C}$ until their use for real-time PCR amplification.

Twenty genes involved in endocytosis, detoxification, respiratory chain, immunity, and apoptosis and three reference genes were assessed (Table 1). Real-time PCR reactions were performed in a LightCycler 480 (Roche) to quantify cDNA amplification. PCR reactions were performed in 96-well plates with the kit GoTaq ${ }^{\circledR}$ qPCR Master Mix (Promega) which contains the $5 \times$ buffer, the Taq polymerase, $\mathrm{MgCl}_{2}$, dNTP, and SybrGreen. For each reaction, $2 \mu \mathrm{L}$ of a genespecific primer pair, at a final concentration of $5 \mu \mathrm{M}$ for each primer (Table 1), $12.5 \mu \mathrm{L}$ of qPCR Master Mix mixed with $6.5 \mu \mathrm{L}$ of RNA free water, and $5 \mu \mathrm{L}$ of cDNA were added to each wells and mixed to achieve PCR amplifications.

The amplification program began by one cycle at $95{ }^{\circ} \mathrm{C}$ for $10 \mathrm{~min}$, then 40 amplification cycles at $95^{\circ} \mathrm{C}$ for $30 \mathrm{~s}, 60^{\circ} \mathrm{C}$ 
Table 1 List of the genes, accession numbers, and specific primers used in the qPCR analyses

\begin{tabular}{|c|c|c|c|}
\hline Function & Gene & Accession number & Specific primers $\left(5^{\prime}-3^{\prime}\right)$ \\
\hline \multirow[t]{6}{*}{ Reference } & \multirow[t]{2}{*}{$\beta$-actine } & \multirow[t]{2}{*}{ A4L694 } & GATGGATGGTCCAGACTCGTa \\
\hline & & & GGTCTGGATCGGTGGTTCTAb \\
\hline & \multirow[t]{2}{*}{ rpl7 } & \multirow[t]{2}{*}{ P18124 } & CACCATCGTTGAAGTGGTTGa \\
\hline & & & CTTCAAACAGGCTGCCAACTb \\
\hline & \multirow[t]{2}{*}{ ef $1 \alpha$} & \multirow[t]{2}{*}{ J9Z6R5 } & CTTCGTGCCAATCTCTGGATa \\
\hline & & & TTCCTCTCTACAGCCCAACCb \\
\hline \multirow[t]{6}{*}{ Endocytosis } & \multirow[t]{2}{*}{ cltl } & \multirow[t]{2}{*}{ Q00610 } & GCAAACATCACACAGGTTGCa \\
\hline & & & CGTGCGTAGTTGGACACATTb \\
\hline & \multirow[t]{2}{*}{ cav } & \multirow[t]{2}{*}{ P51636 } & GTCCAGCACCATACGTGGTTa \\
\hline & & & AACTGTTGACCACCCTCTGTGb \\
\hline & \multirow[t]{2}{*}{ flot } & \multirow[t]{2}{*}{ O75955 } & TCTTGGGCAAGTCAGAGAGCa \\
\hline & & & CTCCTCGACTGTCATGTTGCb \\
\hline \multirow[t]{2}{*}{ Detoxification } & \multirow[t]{2}{*}{$\mathrm{mt}$} & \multirow[t]{2}{*}{ EF185126 } & CGGCTATCTCCCGCGAa \\
\hline & & & AGCTTTTACCAGAACCAAACAGTb \\
\hline \multirow[t]{4}{*}{ Respiratory chain } & \multirow[t]{2}{*}{$\operatorname{cox} 1$} & \multirow[t]{2}{*}{ Q9G2B4 } & CCTGTTTGGAGAAAGGGTCAa \\
\hline & & & CCGTGGCATTCCACTTATTCb \\
\hline & \multirow[t]{2}{*}{$12 \mathrm{~s}$} & \multirow[t]{2}{*}{ EF446612 } & AGCATTACTATGTTACGACTTACCTCAa \\
\hline & & & AGTTCAGGTAGACGTGTAGGGb \\
\hline \multirow[t]{8}{*}{ Oxidative stress } & \multirow[t]{2}{*}{$\operatorname{sod} 2$} & \multirow[t]{2}{*}{ P04179 } & CCAGGCTAATGGCAGACTTCa \\
\hline & & & GTAGGCATGCTCCCAAACATb \\
\hline & sod1 & U3PWG5 & CCAGCAGCCAGACCAGTTATa \\
\hline & & & AGGGAGACGCTAATGTGTCGb \\
\hline & cat & A4L695 & CACCAGGTGTCCTTCCTGTTa \\
\hline & & & CTCAGCATTCACCAGCTTGAb \\
\hline & gpx 7 & Q96SL4 & AGGATGCATCTGAAGCTTGGa \\
\hline & & & CGTTCACCACATGTCCATTCb \\
\hline Immunity & $\operatorname{atg} 13$ & $\mathrm{O} 75143$ & CTCAGCTGTCCGTAACGAGATa \\
\hline & & & AAGTGCATTCTGAGGCGAAGb \\
\hline & $\operatorname{atg} 12$ & O94817 & ССТСТCAАCTGCССАТТTCТа \\
\hline & & & GTACACCAACGAGTCCTTTGCb \\
\hline & gal & P17931 & TACTGACTTCCCGCTCTTCGa \\
\hline & & & CACTTTGATGTGCGCTTCCb \\
\hline & bd3 & F6M2J7 & ACGCTGGACTGGCAGTATCTa \\
\hline & & & GAGCCTTCGGTAATGCCATAb \\
\hline & c3 & P01024 & ACGCTGGAAGATAACCCGTAa \\
\hline & & & ACACTTTCCAGCAGCGTCTTb \\
\hline Apoptosis & bcl2 & P10415 & AAGGAACAGGTCCATTCACGa \\
\hline & & & GGGACGGATTGTTGGTGTTb \\
\hline & p53 & P04637 & TCCTGCCACAGTCACAAATGa \\
\hline & & & GTCGAGATTTTCCCTCCTTAGCb \\
\hline & bax & Q07812 & AAAGGGGAGGATGGGAGATa \\
\hline & & & GCTATAACTGCCCCTGCTGTb \\
\hline & gadd45 & P24522 & GGAGCAGGTGATGCTGTGTAa \\
\hline & & & CCAGCAGTGTGCCTCAATAAb \\
\hline
\end{tabular}

${ }^{\mathrm{a}}$ Forward primer

${ }^{\mathrm{b}}$ Reverse primer

for $30 \mathrm{~s}$, and $72{ }^{\circ} \mathrm{C}$ for $30 \mathrm{~s}$. Each amplification specificity was checked with the PCR product dissociation curve. It was obtained by following the SybrGreen fluorescence level during a gradual heating of the PCR products from 60 to $95^{\circ} \mathrm{C}$. 
Relative quantification of each gene expression level was normalized according to the gene expression of three reference genes: $\beta$-actin, efl $\alpha$, and rpl7 (according to the GeNorm method). The expression of efl $\alpha$ varied between exposure conditions $(p>0.05)$ and was thus not used for normalization. Differential gene expression was calculated using the $2^{-\Delta \Delta \mathrm{Ct}}$ method as described by Livak and Schmittgen (2001). $\Delta \mathrm{Ct}$ represents the difference between the cycle threshold $(\mathrm{Ct})$ of a specific gene and the $\mathrm{Ct}$ of the geometric mean of the $\mathrm{Ct}$ of the two reference genes. Induction factors of gene expression were calculated in comparison with the controls (not exposed to gold) according to the following equation:

$\mathrm{IF}=\frac{2^{-\Delta \Delta \mathrm{Ct} \text { exposed }}}{2^{-\Delta \Delta \mathrm{Ct} \text { control }}}$

\section{Statistical analysis}

Due to the non-normal distribution of the data, statistical analyses were carried out between controls and exposed bivalves, using the non-parametrical Kruskal-Wallis test using XLStat software (version 2011.2.05, 1995-2011 Addinsoft). For all statistical results, a probability of $p<0.05$ was considered significant.

\section{Results}

Whole-body concentrations were measured for AuNPs and $\mathrm{AuCl}(\mathrm{OH})_{3}{ }^{-}$accumulations to characterize the whole burden of gold accumulated after waterborne and dietary exposures in order to calculate constant rates.

\section{Gold uptake from water}

C. fluminea were exposed to $\mathrm{AuNPs}$ and $\mathrm{AuCl}(\mathrm{OH})_{3}{ }^{-}$at concentrations up to 24 and $5 \mathrm{mg} / \mathrm{L}$ respectively and for 24 and 3 h (Fig. 1). Gold uptake in C. fluminea increased with increasing concentrations of $\mathrm{AuNPs}$ and $\mathrm{AuCl}(\mathrm{OH})_{3}{ }^{-}$for exposure concentrations up to $12 \mathrm{mg} / \mathrm{L}\left(50.46 \mu \mathrm{mol} \mathrm{L}{ }^{-1}\right)$ and $1.5 \mathrm{mg} / \mathrm{L}\left(10.15 \mu \mathrm{mol} \mathrm{L}{ }^{-1}\right)$, respectively. Then, saturation was reached as shown by the Michaelis-Menten equation model (dotted lines). Saturation was reached earlier in clams exposed to $\mathrm{AuCl}(\mathrm{OH})_{3}{ }^{-}$compared to AuNPs, although they were exposed to lower gold concentrations and for a shorter time. The binding site capacity $\mathrm{B}_{\max }$ which defines the maximum level of accumulation into the clams was higher for AuNPs than for its ionic form $(23.9 \pm 6.5$ and $0.12 \pm$ $0.01 \mu \mathrm{mol} \mathrm{g}^{-1}$, respectively), as well as the gold concentration in water at half saturation $\left(k d_{\mathrm{AuNP}}=58.6 \pm 34.6\right.$ and $k d_{\mathrm{AuCl}(\mathrm{OH})_{3-}}=0.84 \pm 0.43 \mu \mathrm{mol} \mathrm{L}^{-1}$, respectively) (Table 1$)$. The uptake rate constants from water $k u w$ were determined from the slopes of the regressions of the linear part of the curves and were significantly higher $(p=0.09)$ for AuNPs $\left(0.28 \pm 0.06 \mathrm{~L} \mathrm{~g} \mathrm{~g}^{-1} \mathrm{day}^{-1}\right)$ than for $\mathrm{AuCl}(\mathrm{OH})_{3}{ }^{-}(0.03 \pm$ $0.004 \mathrm{~L} \mathrm{~g}^{-1}$ day $^{-1}$ ).

\section{Gold uptake from food}

C. fluminea were exposed to green algae for $4 \mathrm{~h}$ that had previously been exposed to $\mathrm{AuNPs}$ and $\mathrm{AuCl}(\mathrm{OH})_{3}{ }^{-}$at concentrations up to 48 and $24 \mathrm{mg} / \mathrm{L}$, respectively, for $4 \mathrm{~h}$. Gold concentrations were 24 to $36 \%$ higher in algae after $\mathrm{AuCl}(\mathrm{OH})_{3}{ }^{-}$exposure compared to AuNPs. However, C. fluminea exposed to ionic gold accumulated around 30 times less than those exposed to AuNPs with accumulations for the $24 \mathrm{mg} / \mathrm{L}$ condition of $0.18 \pm 0.03$ and $5.26 \pm 2.05$, respectively. The saturation point for $\mathrm{AuCl}(\mathrm{OH})_{3}{ }^{-}$was reached for the highest concentration tested $(24 \mathrm{mg} / \mathrm{L}$, corresponding to $773 \mu \mathrm{mol}[\mathrm{Au}] / \mathrm{g}$ of algae), whereas no saturation was reached for AuNPs at $48 \mathrm{mg} / \mathrm{L}$ (corresponding to $1144 \mu \mathrm{mol}[\mathrm{Au}] / \mathrm{g}$ of algae). The binding site capacity $\mathrm{B}_{\max }$ for $\mathrm{AuCl}(\mathrm{OH})_{3}{ }^{-}$was $0.19 \pm 0.02 \mu \mathrm{mol} \mathrm{g}^{-1}$ and $k d_{\mathrm{AuCl}(\mathrm{OH}) 3-}$ in algae was $49.63 \pm 26.50 \mu \mathrm{mol} \mathrm{L}^{-1}$. The food uptake rate constants $k u f$ calculated from the slopes of the linear parts of curves were significantly higher $(p=0.018)$ for AuNPs than for $\mathrm{AuCl}(\mathrm{OH})_{3}{ }^{-}(0.009 \pm 0.002$ and $0.001 \pm$ $0.0002 \mathrm{~g} \mathrm{~g}^{-1}$ day $^{-1}$, respectively).

\section{Elimination of gold}

C. fluminea were exposed to 12 and $24 \mathrm{mg} / \mathrm{L}$ of AuNPs and $\mathrm{AuCl}(\mathrm{OH})_{3}{ }^{-}$respectively for $48 \mathrm{~h}$ before being held in clean water for 28 days of elimination. No gain or loss of weight in clams was observed throughout the elimination duration $(p=$ 0.128 for AuNPs and $p=0.313$ for $\left.\mathrm{AuCl}(\mathrm{OH})_{3}{ }^{-}\right)$. The elimination rate constants $k e$ were determined from nonlinear regressions using a single exponential loss equation $\left(\mathrm{y}=\mathrm{ae}^{-k e x}\right)$ (Fig. 1; Table 2). Gold was eliminated relatively rapidly after being incorporated into tissues from waterborne AuNP and $\mathrm{AuCl}(\mathrm{OH})_{3}{ }^{-}$exposures (around 13 and $8 \%$ of loss per day, respectively). The elimination rate constant was significantly higher ( $p=0.002$ ) after AuNP exposure, meaning that elimination was faster in $C$. fluminea exposed to AuNPs compared to $\mathrm{AuCl}(\mathrm{OH})_{3}{ }^{-}$.

\section{Biodynamic parameters}

The ingestion rate (IR) was calculated for both gold forms, as reflecting the quantity of gold ingested per day. The results presented in Table 1 show that the IR was higher for AuNPs than $\mathrm{AuCl}(\mathrm{OH})_{3}{ }^{-}$, averaging $0.038 \pm 0.009 \mathrm{~g} \mathrm{~g}^{-1} \mathrm{day}^{-1}$ and $0.011 \pm 0.008 \mathrm{~g} \mathrm{~g}^{-1} \mathrm{day}^{-1}$, respectively. Nonetheless, these values are relatively low and support the observations made during the experiments, which pointed out valve closures of 

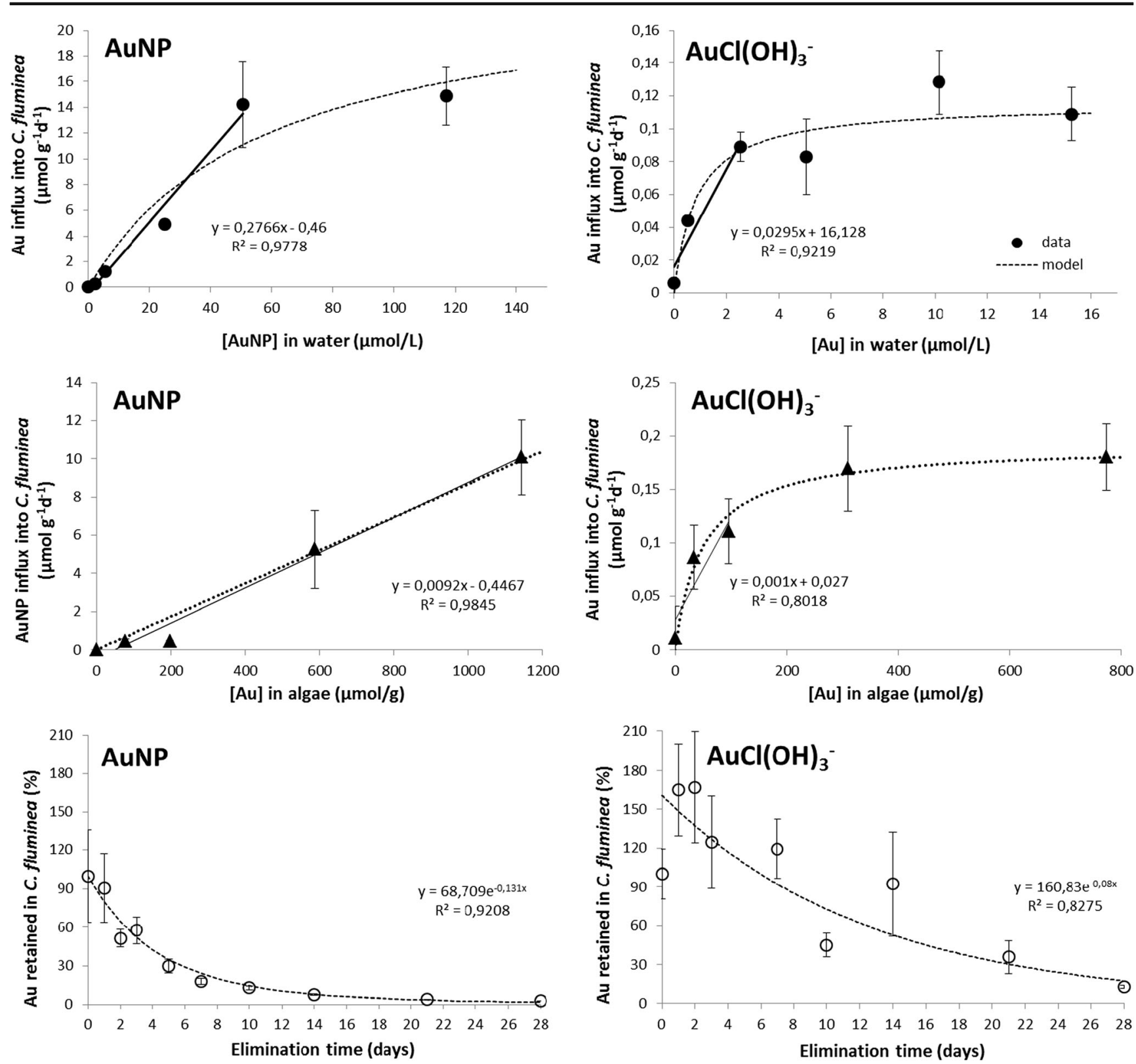

Fig. 1 Gold uptake rates in C. fluminea after waterborne and dietborne exposures. Solid circles are for the waterborne exposure ( 24 and $3 \mathrm{~h}$ for $\mathrm{AuNP}$ and $\mathrm{AuCl}(\mathrm{OH}) 3-$, respectively). Solid triangles are for the dietborne exposure $(4 \mathrm{~h})$. Open circles are for the elimination

C. fluminea for the highest gold concentrations tested. The assimilation efficiency (AE) reflects the proportion of gold assimilated into the organisms after elimination. The AE was two times lower in clams exposed to AuNPs compared to $\mathrm{AuCl}(\mathrm{OH})_{3}{ }^{-}$, averaging $38.2 \pm 7.3$ and $76.1 \pm 6.7 \%$, respectively, suggesting a better excretion of AuNPs.

\section{Gene expression in response to AuNP exposure}

As shown in Table 3 and Fig. 2, genes were mainly overexpressed after waterborne exposure to AuNPs. Clams showed a strong upregulation of several genes involved into

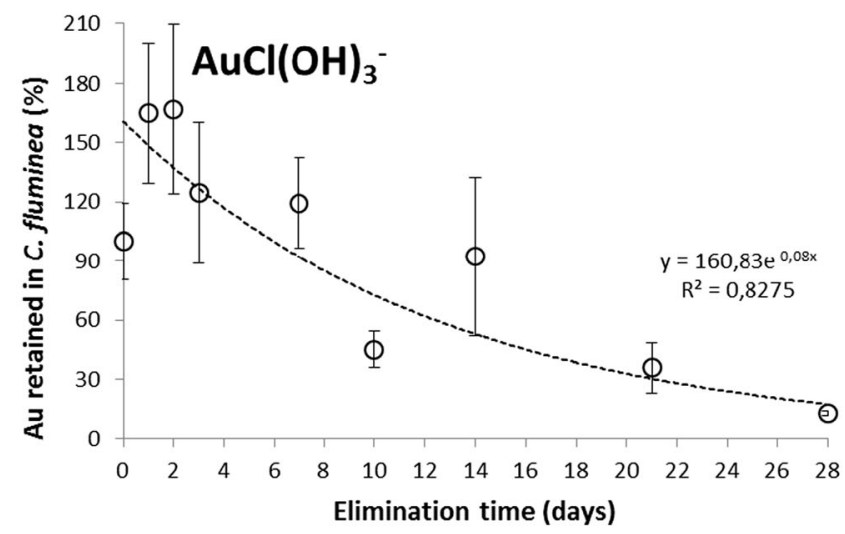

experiment (28 days). Solid lines represent the linear regression, dotted lines represent nonlinear regression fits to Michaelis-Menten equation (Eq. 5)

endocytosis (cltl: 5.05-7.72-fold change), oxidative stress (sod1: 3.3-7.5), immune system (c3: 2.97-6.47), and apoptosis (bax: 3.78-7) for concentrations ranging from 1 to $24 \mathrm{mg} /$ L. No clear dose-dependent effect was observed between AuNP treatments. Very few significant differences were observed after dietborne exposure to AuNPs, probably due to the low accumulation. Cav was slightly repressed in the $12 \mathrm{mg} / \mathrm{L}$ condition (0.45), as well as gal and $b d 3$, involved in immunity $(0.54$ and 0.42 , respectively for $12 \mathrm{mg} / \mathrm{L}$ ).

In the elimination experiment, at the end of the 48-h waterborne exposure to AuNPs, several genes were downregulated, especially those involved in oxidative stress and 
Table 2 Biodynamic parameters and metal binding characteristics $($ mean \pm SE)

\begin{tabular}{lll}
\hline & AuNP & $\mathrm{AuCl}(\mathrm{OH})_{3}{ }^{-}$ \\
\hline Biodynamic parameters & & \\
$k u w\left(\mathrm{~L} \mathrm{~g}^{-1} \mathrm{day}^{-1}\right)$ & $0.28 \pm 0.06$ & $0.03 \pm 0.004$ \\
$k u f\left(\mathrm{~g} \mathrm{~g}^{-1} \mathrm{day}^{-1}\right)$ & $0.009 \pm 0.002$ & $0.001 \pm 0.0002$ \\
$k e\left(\mathrm{day}^{-1}\right)$ & $0.131 \pm 0.008$ & $0.076 \pm 0.006$ \\
$\mathrm{IR}\left(\mathrm{g} \mathrm{g}^{-1} \mathrm{day}^{-1}\right)$ & $0.060-0.013$ (mean: $0.038 \pm 0.009)$ & $0.001 \pm 0.044$ (mean: $0.011 \pm 0.008)$ \\
$\mathrm{AE}(\%)$ & $16.7-58.3$ (mean: $38.2 \pm 7.3)$ & $51.1-89.3$ (mean: $76.1 \pm 6.7)$ \\
Metal binding characteristics & & \\
$\left.\mathrm{B}_{\text {max water }}(\mu \mathrm{mol} \mathrm{g})^{-1}\right)$ & $23.94 \pm 6.54$ & $0.12 \pm 0.01$ \\
$\mathrm{~K}_{\text {metal water }}(\mu \mathrm{mol} \mathrm{L}$ & $0.84 \pm 0.43$ \\
$\mathrm{~B}_{\text {max food }}\left(\mu \mathrm{mol} \mathrm{g}^{-1}\right)$ & $58.65 \pm 34.57$ & $0.19 \pm 0.02$ \\
$\mathrm{~K}_{\text {metal food }}\left(\mu \mathrm{mol} \mathrm{L}^{-1}\right)$ & $/$ & $49.63 \pm 26.50$ \\
\hline
\end{tabular}

immune responses. After 1 day of elimination, the trend was reversed and several genes involved in detoxification, respiratory chain, immunity, and apoptosis were upregulated (for instance $m t: 1.94, \operatorname{cox} 1: 4.18$, atg13: 2.27, gad45: 2.33). After 2 days, we also observed the implementation of responses against the oxidative stress ( $\operatorname{sod} 2: 1.53$; cat: 2.58 ), as well as mechanisms of endocytosis (cav: 2.53; flot: 2.28), which lasted until day 3. Between days 3 and 7, most of the genes tested were downregulated, and gene expressions were no longer significantly different from control after 14 days of elimination.

\section{Gene expression in response to $\mathrm{AuCl}(\mathrm{OH})_{3}{ }^{-}$exposure}

Results for ionic gold showed several trends compared to gold nanoparticles, with both up and downregulations after waterborne exposure, as shown in Fig. 2. The waterborne exposure to $\mathrm{AuCl}(\mathrm{OH})_{3}{ }^{-}$resulted in differential gene expressions for treatments from 0.5 to $5 \mathrm{mg} / \mathrm{L}$, but with lower responses for the 1 and $1.5 \mathrm{mg} / \mathrm{L}$ conditions. Trends were less marked than for AuNP exposures within gene categories, with some genes upregulated and others downregulated. Clathrin-dependent genes of endocytosis were activated, but not caveolindependent ones. Upregulations were also observed for genes involved in detoxification ( $m t$ : 1.30-3.32), and respiratory chain (cox1: 1.57-2.15; $12 s$ : 0.66-1.67). All genes against oxidative stress were upregulated (for instance sod2: 1.492.62; gpx7: 1.68-2.79) except segpx which was repressed. Conversely, all genes involved in immune responses were downregulated (for instance gal: $0.28-0.44$; bd3: 0.26-0.48), except $c 3$. The apoptosis response was balanced between induction and repression of genes. The dietborne exposure did not lead to any significant differential gene expression among all genes tested.

The elimination experiment showed an early induction of genes involved in oxidative stress and apoptosis (days 0 and 1). It was then followed by the downregulation of several genes of endocytosis, oxidative stress, immunity, and apoptosis (for instance cav: 0.27 ; cat: 0.40 ; c3: $0.21-$ $0.44)$; bax: $0.41-0.50$ at day 2 and day 3$)$. After 7 days of elimination, a few genes were induced again (12 s, gpx7, $\operatorname{atg} 12$, bax) but at the end of the experiment, there was no more response involving apoptosis or respiratory chain, and genes of endocytosis, oxidative stress, and immunity were downregulated. No differential expression of the $m t$ gene was observed throughout the elimination experiment.

\section{Discussion}

\section{Gold uptake and elimination from water}

Our results showed that the rate constant for Au uptake is higher for AuNPs than for $\mathrm{AuCl}(\mathrm{OH})_{3}{ }^{-}(k u w=0.28$ and $0.03 \mathrm{~L} \mathrm{~g}^{-1} \mathrm{day}^{-1}$, respectively). It means that $C$. fluminea accumulates more gold in its nanoparticulate forms under the same exposure conditions. This result is quite surprising, as other studies on different metal nanoparticles reported opposite trends. For example, Croteau et al. (2011, 2014) showed that snails exposed to copper oxide nanoparticles and to citrate silver nanoparticles accumulated more metals when in their ionic forms. However, the uptake efficiency depends on the nanoparticle surface chemistry as well as its physical properties (Levy et al. 2010). Indeed, citrate Ag nanoparticles are negatively charged, which make them less likely to be accumulated by cells, compared to the ionic form of $\mathrm{Ag}\left(\mathrm{Ag}^{+}\right)$. The accumulation of gold nanoparticles seems to follow a different pathway, independent of coating properties. Indeed, a study conducted on the marine bivalve species Ruditapes philippinarum also showed that gold accumulation occurred faster and reached higher values within the digestive gland after waterborne exposure to Au-citrate 
Table 3 Differential gene expression (DGE) for the three experiments: waterborne, dietborne, and elimination (mean, $n=4)$. Only DGE significantly different from controls are presented in the table (Kruskal-Wallis test, $p<0.05$ )

\begin{tabular}{|c|c|c|c|c|c|c|c|c|c|c|c|c|c|c|c|c|c|c|}
\hline \multirow[t]{2}{*}{ AuNP } & & \multicolumn{6}{|c|}{ Waterborne (ppm) } & \multicolumn{4}{|c|}{ Dietborne (ppm) } & \multicolumn{7}{|c|}{ Elimination (days) } \\
\hline & & 0.5 & 1 & 5 & 12 & 24 & & 5 & 12 & 24 & 48 & 0 & 1 & 2 & 3 & 7 & 10 & 14 \\
\hline \multirow[t]{3}{*}{ Endocytosis } & cltl & & 5.1 & 7.72 & 5.05 & 6.79 & & & & & & & & 1.83 & & & & \\
\hline & $c a v$ & & & & & & & & 0.45 & & & & & 2.09 & 2.53 & 0.38 & 0.5 & \\
\hline & flot & & 2.78 & 3.75 & & & & & & & & & & 2.14 & 2.28 & & 0.41 & \\
\hline Detoxification & $m t$ & & & & & 2.16 & & & & & & & 1.94 & 1.78 & 1.53 & & & \\
\hline \multirow[t]{2}{*}{ Respiratory chain } & $\operatorname{cox} 1$ & & & & 2.43 & & & & & & & 1.9 & 4.18 & 6.89 & 3.95 & & 0.45 & \\
\hline & $12 s$ & & & & 2.25 & & & & & & & & & 1.73 & & & & \\
\hline \multirow[t]{5}{*}{ Oxidative stress } & sod2 & & 2.68 & 4.66 & 2.81 & 2.79 & & & & & & & & 1.53 & 1.76 & & 0.58 & \\
\hline & sodl & & 3.3 & 7.5 & 3.83 & 4.07 & & & & & & 0.23 & 0.27 & & 0.29 & & & \\
\hline & cat & & 2.42 & & & & & & & & & 0.58 & & 2.58 & 3.37 & 0.48 & 0.39 & \\
\hline & gpx7 & & 2.9 & 4.3 & 2.43 & 2.49 & & & & & & & & & & & & \\
\hline & segpx & & & & & & & & & & & 0.56 & & & & 0.37 & 0.45 & \\
\hline \multirow[t]{5}{*}{ Immunity } & $\operatorname{atg} 13$ & & & & & & & & & & & & 2.27 & 2.5 & 2.23 & 0.64 & 0.43 & \\
\hline & $\operatorname{atg} 12$ & & 3.4 & 5.67 & 3.61 & 2.76 & & & & & & & 1.44 & 1.9 & & & & \\
\hline & gal & & & & & 0.35 & & & 0.54 & & & & 1.37 & 1.65 & 2.35 & 0.48 & 0.61 & \\
\hline & $b d 3$ & & & & & & & & 0.42 & 0.35 & 0.29 & 0.66 & & & & 0.59 & & \\
\hline & $c 3$ & & 3.62 & 6.47 & 2.97 & 3.03 & & & & & & 0.37 & & & & & 0.46 & \\
\hline \multirow[t]{4}{*}{ Apoptosis } & $b c l 2$ & & 3.19 & 6.02 & 3.07 & 3.2 & & & & & & 0.56 & 2.18 & 1.68 & & & 0.62 & \\
\hline & p53 & & & & & 1.74 & & & & & & & & & & & 0.63 & \\
\hline & bax & & 3.78 & 7,00 & 4.1 & 3.92 & & & & & & & & & & & & \\
\hline & $\operatorname{gad} 45$ & & & & & & & & & & & & 2.33 & 2.42 & 1.84 & & 0.54 & \\
\hline \multirow[t]{2}{*}{$\mathrm{AuCl}(\mathrm{OH})_{3}{ }^{-}$} & & \multicolumn{6}{|c|}{ Waterborne (ppm) } & \multicolumn{4}{|c|}{ Dietborne (ppm) } & \multicolumn{7}{|c|}{ Elimination (days) } \\
\hline & & 0.1 & 0.5 & 1 & 1.5 & 2 & 5 & 1 & 5 & 12 & 24 & 0 & 1 & 2 & 3 & 7 & 10 & 14 \\
\hline \multirow[t]{3}{*}{ Endocytosis } & cltl & & 2.16 & 2.12 & 2.22 & & 2.27 & & & & & & & & 0.41 & & & \\
\hline & $c a v$ & & 0.42 & 0.25 & 0.32 & 0.3 & & & & & & & & 0.27 & & & 0.62 & 0.48 \\
\hline & flot & & 1.25 & & & & & & & & & & & 0.59 & 0.49 & & & 0.49 \\
\hline Detoxification & $m t$ & & 1.3 & 3.32 & & & 1.93 & & & & & & & & & & & \\
\hline \multirow[t]{2}{*}{ Respiratorychain } & $\operatorname{cox} 1$ & & 1.65 & & & 1.57 & 2.15 & & & & & & 1.85 & & & & & \\
\hline & $12 s$ & & & & & 0.66 & 1.67 & & & & & 1.64 & & & & 1.98 & & \\
\hline \multirow[t]{5}{*}{ Oxidative stress } & $\operatorname{sod} 2$ & & 2.32 & & & 1.49 & 2.62 & & & & & & & & & & & \\
\hline & sodl & & 3.46 & 2.92 & 4.09 & 2.02 & 3.94 & & & & & & & 0.53 & 0.41 & & 1.56 & \\
\hline & cat & & & & & 0.63 & & & & & & & & 0.4 & & & & 0.54 \\
\hline & gpx7 & & 1.81 & 2.79 & & 1.68 & 2.31 & & & & & & & & & 2.07 & 1.72 & \\
\hline & segpx & & 0.53 & 0.38 & & 0.35 & 0.51 & & & & & & & 0.59 & & & 0.73 & \\
\hline \multirow[t]{5}{*}{ Immunity } & $\operatorname{atg} 13$ & & & & & 0.52 & & & & & & & & 0.53 & 0.39 & & & 0.64 \\
\hline & $\operatorname{atg} 12$ & & & & & 0.64 & & & & & & & & & 0.49 & 2.35 & 1.49 & \\
\hline & gal & & 0.44 & 0.29 & 0.28 & 0.36 & & & & & & & & 0.23 & 0.54 & & & 0.49 \\
\hline & $b d 3$ & & 0.42 & & 0.26 & 0.29 & 0.48 & & & & & & & 0.39 & 5.67 & & 0.64 & 0.39 \\
\hline & $c 3$ & & 2.43 & & 2.62 & 1.88 & 2.33 & & & & & & & 0.44 & 0.21 & & & 0.64 \\
\hline \multirow[t]{4}{*}{ Apoptosis } & $b c l 2$ & & 1.34 & & & & 2.29 & & & & & 3.67 & & & & & & \\
\hline & p53 & & & 0.41 & & 0.59 & & & & & & & & & & & & \\
\hline & bax & & 1.45 & & & & & & & & & 1.72 & & & & 2.24 & & \\
\hline & $\operatorname{gad} 45$ & & & & & 0.45 & & & & & & 2.1 & & 0.41 & 0.5 & & & \\
\hline
\end{tabular}

nanoparticles compared to $\mathrm{AuCl}(\mathrm{OH})_{3}{ }^{-}$(García-Negrete et al. 2013). In another study on C. fluminea exposed to AuNPs via trophic route, Renault et al. (2008) showed that AuNPs could penetrate gill and stomach epithelia and were stored into vesicles. They suggested that vesicle genesis could act as a defensive device to protect cells by 

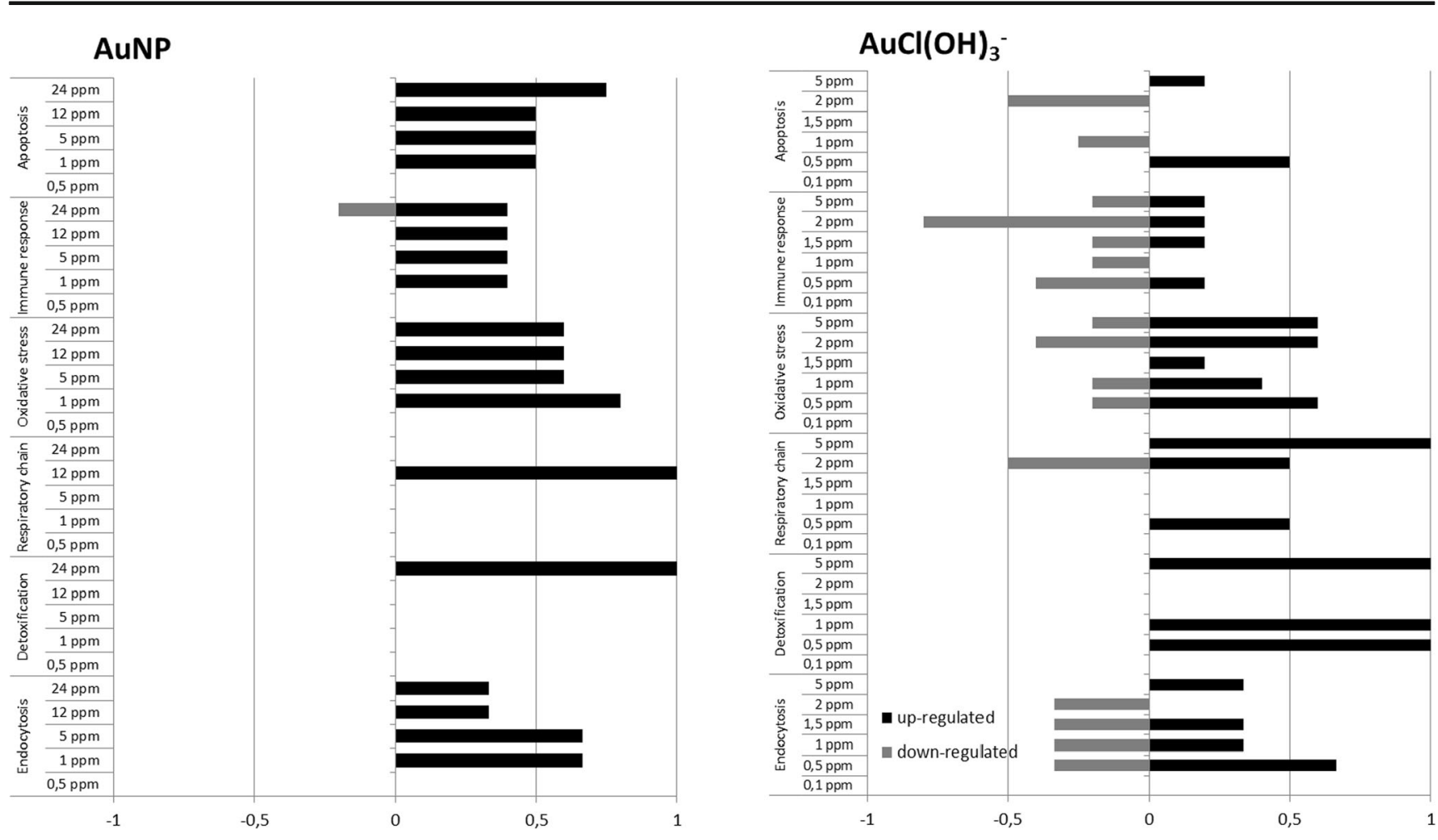

Fig. 2 Ratio of genes up- and downregulated by functional category tested, in clams after waterborne exposure to $\mathrm{AuNPs}$ and $\mathrm{AuCl}(\mathrm{OH}) 3-$

sequestering AuNPs. Several authors suggested that AuNPs remain trapped in endosomal vesicles and are incapable of reaching the cytosol (Levy et al. 2010). Some studies suggested that once ingested, excretion would play an important pathway within the digestive tract to limit AuNP accumulation in organs and may occur after as early as 1 day of exposure (Canesi et al. 2012; GarcíaNegrete et al. 2013). This is consistent with our study and the $k e$ values where we showed a faster elimination of AuNPs compared to $\mathrm{AuCl}(\mathrm{OH})_{3}{ }^{-}$. These results are confirmed by the value of AE which is lower for AuNPs than for $\mathrm{AuCl}(\mathrm{OH})_{3}{ }^{-}$, suggesting a stronger gold accumulation into feces compared to the whole body after AuNP exposure, thus a greater excretion of gold.

\section{Gold uptake from dietary sources}

Gold was around 30 times less accumulated after dietary exposure to AuNPs and $\mathrm{AuCl}(\mathrm{OH})_{3}{ }^{-}$, than after the waterborne exposure. Previous studies showed that the algae Scenedesmus subspicatus used to feed $C$. fluminea was able to convey gold nanoparticles since AuNPs accumulated at the surface of their cell wall (Renault et al. 2008). From our data, we calculated bioconcentration factors (BCFs) of $6.1,11,41.3$, and 75.7 for the 5, 12, 24, and $48 \mathrm{mg} / \mathrm{L}$ treatments respectively, after $4 \mathrm{~h}$ of exposure. Therefore, we would have expected a strong accumulation in clams' tissues. In this study, we measured the gold accumulation in the whole body of $C$. fluminea to get the total body burden, which can depend on the filtration, storage, and excretion capacities of the different organs. For example, it has been shown in a study on C. fluminea exposed to the same AuNPs that gold was preferentially accumulated in the visceral mass after dietary exposure, with concentrations more than 30 times higher than those in the gills after 5 days of feeding with algae exposed to $0.5 \mathrm{mg}$ AuNP/L (Perrier 2017). However, in our study during the trophic exposure, we observed a decrease in the ventilator activity of clams, even more pronounced for high gold concentrations. The valve closure of bivalves could have had a direct impact on gold accumulation through a reduced gill filtration and explain the low concentrations measured in the body, including the visceral mass, and then the low values obtained for the rate constant from food $(k u f)$. Studies suggested that the ionic form of gold was strongly toxic and could directly affect the adjustment of the organism's filtering and ingestion rate (García-Negrete et al. 2013). This statement is in accordance with our results, showing a greater IR for $\mathrm{AuNPs}$ than $\mathrm{AuCl}(\mathrm{OH})_{3}{ }^{-}$. Other nanoparticles and metals have been reported to impair feeding activity of aquatic organisms. For instance, dietary exposures to ZnONPs and AgNPs suppressed feeding rates of the snail Lymnaea stagnalis (Croteau et al. 2011, 2014) and dietary exposure to $\mathrm{Ag}^{3+}$ and AgNP led to a decrease in feeding activity of the bivalve Scrobicularia plana (Buffet et al. 2013). 


\section{Predicting gold uptake from the biodynamic model}

Biodynamic models assume that bioaccumulation is the result of a balance among three mechanisms: uptake rate from water, uptake rate from diet, and elimination rates. Empirical data do not always take into account different exposure routes, and this may explain the poor correlation often observed between environmental concentrations of metals and concentrations in biomonitor species (Luoma and Rainbow 2005). These authors explained that metal forms, taxons, and exposure routes which are integrated in biodynamic models provide a mean to explain the variability of bioaccumulation in nature. This is crucial to better understand the associated toxic effects.

The rate constants determined from our results (Table 1) show that gold mainly accumulates after waterborne exposure in C. fluminea, and to a lower extent after dietborne exposure for both tested forms of gold (very low kuf values). Basically, C. fluminea ingests more AuNPs than $\mathrm{AuCl}(\mathrm{OH})_{3}{ }^{-}$(IR AuNP > IR AuCl(OH $\left.)_{3}{ }^{-}\right)$but eliminates AuNPs more rapidly than $\mathrm{AuCl}(\mathrm{OH})_{3}{ }^{-}$and have a lower assimilation efficiency ( $\mathrm{AE} \mathrm{AuNP}<\mathrm{AE} \mathrm{AuCl}(\mathrm{OH})_{3}{ }^{-}$) probably due to the implementation of better elimination mechanisms, such as excretion ( $k e \mathrm{AuNP}>k e \mathrm{AuCl}(\mathrm{OH})_{3}{ }^{-}$). In our study, we used a range of concentrations of AuNPs and $\mathrm{AuCl}(\mathrm{OH})_{3}{ }^{-}$, reaching values higher than those expected in natural waters, in order to reach saturation and determine the rate constants from the slope of the linear part of the curve. Their incorporation in the biodynamic model will allow predicting accumulation in the organism (Luoma and Rainbow 2005). For example, if we assume a chronic and environmentally relevant dietborne exposure of $5 \mathrm{nmol} \mathrm{L}{ }^{-1} \mathrm{Au}$ in the form of $\mathrm{AuNPs}$ and $\mathrm{AuCl}(\mathrm{OH})_{3}{ }_{3}^{-}$, it gives 16.11 and $29.15 \mathrm{nmol} \mathrm{g}^{-1}$ for $\mathrm{AuNPs}$ and $\mathrm{AuCl}(\mathrm{OH})_{3}{ }^{-}$ accumulated in algae for the trophic exposure respectively, and the clams will accumulate: $1.36 \mathrm{nmol} \mathrm{g}^{-1}$ for AuNPs and $0.17 \mathrm{nmol} \mathrm{g}^{-1} \mathrm{AuCl}(\mathrm{OH})_{3}{ }_{3}^{-}$. This biodynamic model is of particular interest when assessing accumulation capacities of bivalves at concentrations as low as $\mathrm{nmol} \mathrm{L}^{-1}$, especially since such concentrations are difficult to detect with analytical tools, as explained in Croteau et al. (2011). Specifically, biodynamic models are useful tools for aquatic organisms such as bivalves since they can modulate their ventilatory activity when exposed to contaminants and accumulate concentrations that do not reflect the environmental contamination. By integrating different parameters of accumulation and elimination, the biodynamic model presented here represent an integrative tool to monitor bioavailable gold concentrations in bivalves in natural waters, in order to closely estimate their body burden and link it to potential adverse outcomes.

\section{Effects of gold exposure on gene expression}

Hemocytes were sampled in adductor mussels of clams and used to conduct gene expression analyses. Hemolymph cells are responsible for the immune defense of mollusks (Cajaraville and Pal 1995) and have been reported as constituting important targets for NP toxicity (Canesi et al. 2012; Katsumiti et al. 2016), which make them interesting to investigate for gene expression. Several genes involved in endocytosis, detoxification, mitochondrial metabolism, oxidative stress, immunity, and apoptosis were assessed. The most important differential gene expressions (DGEs) were obtained after the waterborne exposure. No DGE was observed for the lowest concentrations tested of $\mathrm{AuNPs}$ and $\mathrm{AuCl}(\mathrm{OH})_{3}{ }^{-}$ ( 0.5 and $0.1 \mathrm{ppm}$, respectively). This means that effects observed occurred for concentrations higher than those found in the environment. It should be kept in mind that we conducted short-term exposures (24 to $48 \mathrm{~h}$ ), but it was long enough to generate DGE. Under chronic exposures at lower concentrations, representative to natural conditions, we might expect effects at the gene level too. Endocytosis was clearly identified as an entry mechanism after $\mathrm{AuNP}$ and $\mathrm{AuCl}(\mathrm{OH})_{3}{ }^{-}$exposures, with the upregulation of clathrin-dependent and independent pathways (flotillin). Endocytosis is widely reported in the literature as being the main entry route of nanoparticles into cells (Conner and Schmid 2003; Doherty and McMahon 2009), but so far, it was less clear for ionic forms of gold. Detoxification was also implemented with the upregulation of the $m t$ gene of clams exposed to $\mathrm{AuCl}(\mathrm{OH})_{3}{ }^{-}$, and to a lesser extent to those exposed to AuNPs. Metallothioneins are well-referenced proteins involved in the metal sequestration in bivalves (Amiard et al. 2006; Baudrimont et al. 2003). However, the lack of response for AuNPs, except for the highest concentrations tested $(24 \mathrm{mg} / \mathrm{L})$, could be explained by the polyethylene glycol (PEG) coating on their surface. PEGylation of NPs has been used traditionally to reduce non-specific interactions with proteins (Dai et al. 2014; Pelaz et al. 2015), and we could assume that this might result in less interaction with metallothioneins. Several genes involved in the response against oxidative stress $(\operatorname{sod} 1, \operatorname{sod} 2$, cat, gpx7) were also upregulated after $\mathrm{AuNP}$ and $\mathrm{AuCl}(\mathrm{OH})_{3}{ }^{-}$ waterborne exposures. It has been demonstrated in different studies that gold exposure could lead to an oxidative stress. For instance, Tedesco et al. (2008) showed that the exposure of Mytilus edulis for $24 \mathrm{~h}$ to $750 \mathrm{ppb}$ of citrate-AuNPs (13 nm) resulted in the upregulation of catalase. Other organisms such as fish have also been reported as undergoing oxidative stress after waterborne exposures to $1.6 \mathrm{mg} / \mathrm{L}$ of citrate and PVP AuNPs $(40 \mathrm{~nm})$, with an upregulation of $g p x 1, \operatorname{gpx} 4$, sod2, and cat. However, this is to our knowledge the first evidence of the induction of an oxidative stress in bivalves exposed to PEG-AuNPs. Indeed, PEG coating are commonly used to avoid the clearance of NPs by the immune system (Gordon and Rice 1988). Our results are quite surprising since they highlight an oxidative stress and a strong immune response, by the upregulation of $\operatorname{atg} 12$ and $c 3$ after the exposure to PEGAuNPs and to a lesser extent after the $\mathrm{AuCl}(\mathrm{OH})_{3}{ }^{-}$exposure 
with genes of immunity mainly downregulated (except c3). The results clearly point out a difference in gene responses for both forms of gold. This is confirmed by the apoptotic response, stronger after AuNP exposure than after $\mathrm{AuCl}(\mathrm{OH})_{3}{ }^{-}$. This denotes the higher apoptotic processes triggered by AuNP exposure compared to its ionic form, potentially leading to cell and individual death.

NP toxicity is often referred as being more hazardous for aquatic life than its ionic counterpart. But recent studies on NPs such as silver NPs have suggested that this could be actually linked to the release of metal ions (Burchardt et al. 2012; Katsumiti et al. 2015). Here, the stability of AuNPs has been checked by using filtration device (Amicon ultracel $3 \mathrm{~K}$ filters, Merck) to separate the dissolved fraction from the particulate one of AuNP solutions at 1 and $10 \mathrm{mg} / \mathrm{L}$ after 1, 24, and $60 \mathrm{~h}$ under 12:12 light and gentle agitation. The $\mathrm{pH}$ values were measured in the tested solutions for the concentrations of 1 and $10 \mathrm{mg} / \mathrm{L}$, and averaged $6.35 \pm 0.18$ and $5.48 \pm 0.43$, respectively, close to the internal $\mathrm{pH}$ of active lysosomes ( $\mathrm{pH}$ around 5). The results showed very good stability in time with 0.018 and $0.08 \%$ of gold dissolved after $1 \mathrm{~h}$ in AuNP solutions at 1 and $10 \mathrm{mg} / \mathrm{L}$ respectively, 0.49 and $0.54 \%$ after $24 \mathrm{~h}$ and 1.7 and $6.6 \%$ after $60 \mathrm{~h}$, respectively (Table 4 ). This means that in our experiments lasting for 24 to $48 \mathrm{~h}$, very little gold was solubilized and that observed effects can predominantly be related to AuNPs themselves. However, it has been shown that under acidic conditions, AuNPs could be oxidized into $\mathrm{Au}^{3+}$ and $\mathrm{AuCl}_{4}{ }^{-}$(Praharaj et al. 2007). Acidic conditions may be encountered by NPs once ingested. Renault et al. (2008) and Jimeno-Romero et al. (2017) demonstrated that AuNPs were sequestered into lysosomal vesicles once inside bivalves where $\mathrm{pH}$ is low, and that it could damage NP coating. This could lead to the release of gold ions contained in each nanoparticle, described as a Trojan horse mechanism by Luoma (2008). To support this assumption, the stability of AuNP has also been checked under very acidic concentrations ( $1 \%$ aqua regia for $1 \mathrm{~h}, \mathrm{pH}=1.32 \pm 0.11$ ) in our study by using Amicon filtration as described above. Results showed a quite important release of gold ions reaching 16.9 and $23.1 \%$

Table 4 Solubilization percentage of gold over time from AuNP solutions at 1 and $10 \mathrm{ppm}$

\begin{tabular}{lll}
\hline AuNP initial concentration (ppm) & Time (h) & Solubilized gold (\%) \\
\hline 1 & 1 & $0.08 \pm 0.06$ \\
& 24 & $0.54 \pm 0.22$ \\
10 & 120 & $1.7 \pm 0.67$ \\
& 1 & $0.18 \pm 0.18$ \\
& 24 & $0.49 \pm 0.15$ \\
$1(1 \%$ aqua regia $)$ & 120 & $6.61 \pm 0.9$ \\
$10(1 \%$ aqua regia $)$ & 1 & 16.89 \\
\hline
\end{tabular}

of total AuNPs for the tested concentrations of 1 and $10 \mathrm{mg} / \mathrm{L}$, respectively. The difference between results obtained after AuNP and $\mathrm{AuCl}(\mathrm{OH})_{3}{ }^{-}$exposures observed here could be related to this internal release phenomenon.

Very few effects were observed for the dietborne exposure to AuNPs and $\mathrm{AuCl}(\mathrm{OH})_{3}{ }^{-}$. As aforementioned, we observed that $C$. fluminea modulated its ventilatory activity when exposed to gold. However, another study conducted on C. fluminea exposed to AuNPs showed the upregulation of the catalase gene in the visceral mass of clams dietary exposed to PEG-AuNPs for 7 days (Renault et al. 2008). The discrepancy between both results could come from the exposure duration. In our study, clams were exposed to contaminated algae for only $4 \mathrm{~h}$. A longer experiment would be suitable since after a closure time, clams will have no choice than filtering for their respiratory and feeding needs.

The elimination experiment clearly followed the response pathway of the waterborne exposure, with greater upregulation of genes after AuNP exposure compared to $\mathrm{AuCl}(\mathrm{OH})_{3}{ }^{-}$, that lasted until 10 days of depuration. Still, results are not exactly similar to those from the waterborne exposure at T0 since the exposure lasted here $48 \mathrm{~h}$ against $24 \mathrm{~h}$ for the waterborne exposure. Other studies conducted on $C$. fluminea have shown long-term effects on gene expression after exposure to metals. For instance, Arini et al. (2014) demonstrated that the response against oxidative stress via the upregulation of catalase lasted for more than 28 days after the contamination with $\mathrm{Cd}$ and $\mathrm{Zn}$ stopped. Other genes such as $12 \mathrm{~s}$ and $m t$ were also upregulated for 14 days after the end of exposure. Given the whole results, we can assume that gene inductions were no longer linked to gold exposure after 14 days of elimination, despite their incomplete decontamination.

\section{Conclusion}

Incorporation of parameters into the biodynamic model shows that the waterborne exposure is the main entry route for gold in $C$. fluminea for both forms of gold. As the ventilatory activity of clams is used for both respiratory and feeding purposes, $C$. fluminea are likely to accumulate important concentrations of metals, including gold, as suggested by the results of this study. As such, they represent good models to monitor the presence of AuNPs into the environment, especially at low environmental concentrations, where they cannot be detected by usual analytical methods. The strong stability of AuNPs used in this study is a major finding in research towards nanoparticle effects on aquatic organisms. Several studies suggest that NP toxicity may actually be related to the release of their counterpart ions, in large quantity. In this study, we showed that AuNPs were very stable and generated more effects at the gene level than ionic gold. These results raise new concerns by showing the actual toxicity of NPs. By the same token, they 
show the importance for further investigations on other metal NPs to test if toxicity is enhanced when NP stability increases.

Acknowledgments The authors thank Marie-Noëlle Croteau for her valuable help on the application and interpretation of the biodynamic model on Corbicula fluminea and Anthony Bertucci for his help on the choice of relevant genes in the hemolymph. We also thank Bruno Etcheverria for his help in field and lab work.

Funding information This work was supported by the Agence Nationale de la Recherche (ANR) in the CITTOXIC-Nano program (ANR-14CE21-0001-01) and the Investments for the Future Program, within the Cluster of Excellence COTE (ANR-10-LABX-45).

\section{References}

Amiard J-C, Amiard-Triquet C, Barka S, Pellerin J, Rainbow P (2006) Metallothioneins in aquatic invertebrates: their role in metal detoxification and their use as biomarkers. Aquat Toxicol 76:160-202

Arini A, Baudrimont M, Feurtet-Mazel A, Coynel A, Blanc G, Coste M, Delmas F (2011) Comparison of periphytic biofilm and filterfeeding bivalve metal bioaccumulation ( $\mathrm{Cd}$ and $\mathrm{Zn}$ ) to monitor hydrosystem restoration after industrial remediation: a year of biomonitoring. J Environ Monit 13:3386-3398

Arini A, Daffe G, Gonzalez P, Feurtet-Mazel A, Baudrimont M (2014) Detoxification and recovery capacities of Corbicula fluminea after an industrial metal contamination $(\mathrm{Cd}$ and $\mathrm{Zn})$ : a one-year depuration experiment. Environ Pollut 192:74-82

Baudrimont M, Andres S, Durrieu G, Boudou A (2003) The key role of metallothioneins in the bivalve Corbicula fluminea during the depuration phase, after in situ exposure to $\mathrm{Cd}$ and $\mathrm{Zn}$. Aquat Toxicol 63:89-102

Buffet P-E, Pan J-F, Poirier L, Amiard-Triquet C, Amiard J-C, Gaudin P, Risso-de Faverney C, Guibbolini M, Gilliland D, Valsami-Jones E (2013) Biochemical and behavioural responses of the endobenthic bivalve Scrobicularia plana to silver nanoparticles in seawater and microalgal food. Ecotoxicol Environ Saf 89:117-124

Burchardt AD, Carvalho RN, Valente A, Nativo P, Gilliland D, Garcìa CP, Passarella R, Pedroni V, Rossi O, Lettieri T (2012) Effects of silver nanoparticles in diatom Thalassiosira pseudonana and Cyanobacterium synechococcus sp. Environ Sci Technol 46: 11336-11344

Cajaraville MP, Pal SG (1995) Morphofunctional study of the haemocytes of the bivalve mollusc Mytilus galloprovincialis with emphasis on the endolysosomal compartment. Cell Struct Funct 20: 355-367

Canesi L, Ciacci C, Fabbri R, Marcomini A, Pojana G, Gallo G (2012) Bivalve molluscs as a unique target group for nanoparticle toxicity. Mar Environ Res 76:16-21

Conner SD, Schmid SL (2003) Regulated portals of entry into the cell. Nature 422:37-44

Croteau M-N, Misra SK, Luoma SN, Valsami-Jones E (2011) Silver bioaccumulation dynamics in a freshwater invertebrate after aqueous and dietary exposures to Nanosized and ionic Ag. Environ Sci Technol 45:6600-6607. https://doi.org/10.1021/es200880c

Croteau M-N, Misra SK, Luoma SN, Valsami-Jones E (2014) Bioaccumulation and toxicity of $\mathrm{CuO}$ nanoparticles by a freshwater invertebrate after waterborne and dietborne exposures. Environ Sci Technol 48:10929-10937
Dai Q, Walkey C, Chan WC (2014) Polyethylene glycol backfilling mitigates the negative impact of the protein corona on nanoparticle cell targeting. Angew Chem Int Ed 53:5093-5096

Daniel M-C, Astruc D (2004) Gold nanoparticles: assembly, supramolecular chemistry, quantum-size-related properties, and applications toward biology, catalysis, and nanotechnology. Chem Rev 104:293346

Diegoli S, Manciulea AL, Begum S, Jones IP, Lead JR, Preece JA (2008) Interaction between manufactured gold nanoparticles and naturally occurring organic macromolecules. Sci Total Environ 402:51-61

Doherty GJ, McMahon HT (2009) Mechanisms of endocytosis. Annu Rev Biochem 78:857-902

García-Negrete C, Blasco J, Volland M, Rojas T, Hampel M, LaprestaFernández A, De Haro MJ, Soto M, Fernández A (2013) Behaviour of Au-citrate nanoparticles in seawater and accumulation in bivalves at environmentally relevant concentrations. Environ Pollut 174: 134-141

Giljohann DA, Seferos DS, Daniel WL, Massich MD, Patel PC, Mirkin CA (2010) Gold nanoparticles for biology and medicine. Angew Chem Int Ed 49:3280-3294

Gordon D, Rice J (1988) Opsonin-dependent and independent surface phagocytosis of $S$. aureus proceeds independently of complement and complement receptors. Immunology 64:709

Hull MS, Chaurand P, Rose J, Auffan M, Bottero JY, Jones JC, Schultz IR, Vikesland PJ (2011) Filter-feeding bivalves store and biodeposit colloidally stable gold nanoparticles. Environ Sci Technol 45:65926599

Jimeno-Romero A, Izagirre U, Gilliland D, Warley A, Cajaraville MP, Marigómez I, Soto M (2017) Lysosomal responses to different gold forms (nanoparticles, aqueous, bulk) in mussel digestive cells: a trade-off between the toxicity of the capping agent and form, size and exposure concentration. Nanotoxicology 11:658-670

Joubert Y, Pan J-F, Buffet P-E, Pilet P, Gilliland D, Valsami-Jones E, Mouneyrac C, Amiard-Triquet C (2013) Subcellular localization of gold nanoparticles in the estuarine bivalve Scrobicularia plana after exposure through the water. Gold Bull 46:47-56

Katsumiti A, Gilliland D, Arostegui I, Cajaraville MP (2015) Mechanisms of toxicity of Ag nanoparticles in comparison to bulk and ionic $\mathrm{Ag}$ on mussel hemocytes and gill cells. PLoS One 10: e0129039

Katsumiti A, Arostegui I, Oron M, Gilliland D, Valsami-Jones E, Cajaraville MP (2016) Cytotoxicity of $\mathrm{Au}, \mathrm{ZnO}$ and $\mathrm{SiO} 2 \mathrm{NPs}$ using in vitro assays with mussel hemocytes and gill cells: relevance of size, shape and additives. Nanotoxicology 10:185-193

Kimling J, Maier M, Okenve B, Kotaidis V, Ballot H, Plech A (2006) Turkevich method for gold nanoparticle synthesis revisited. J Phys Chem B 110:15700-15707

Lapresta-Fernández A, Fernández A, Blasco J (2012) Nanoecotoxicity effects of engineered silver and gold nanoparticles in aquatic organisms. TrAC Trends Anal Chem 32:40-59

Levy R, Shaheen U, Cesbron Y, See V (2010) Gold nanoparticles delivery in mammalian live cells: a critical review. Nanotechnol Rev 1: 4889

Livak KJ, Schmittgen TD (2001) Analysis of relative gene expression data using real-time quantitative PCR and the 2(-Delta Delta C(T)) method. Methods 25:402-408

Luoma SN (2008) Silver nanotechnologies and the environment : old problems or new challenges The Project on Emerging Nanotechnologies Report 15

Luoma SN, Rainbow PS (2005) Why is metal bioaccumulation so variable? Biodynamics as a unifying concept. Environ Sci Technol 39: 1921-1931

Navarro E, Piccapietra F, Wagner B, Marconi F, Kaegi R, Odzak N, Sigg L, Behra R (2008) Toxicity of silver nanoparticles to Chlamydomonas reinhardtii. Environ Sci Technol 42:8959-8964 
Nel A, Xia T, Mädler L, Li N (2006) Toxic potential of materials at the nanolevel. Science 311:622-627

Paciotti GF, Myer L, Weinreich D, Goia D, Pavel N, McLaughlin RE, Tamarkin L (2004) Colloidal gold: a novel nanoparticle vector for tumor directed drug delivery. Drug Deliv 11:169-183

Pelaz B, del Pino P, Maffre P, Hartmann R, Gallego M, Rivera-Fernandez S, de la Fuente JM, Nienhaus GU, Parak WJ (2015) Surface functionalization of nanoparticles with polyethylene glycol: effects on protein adsorption and cellular uptake. ACS Nano 9:6996-7008

Perrier F (2017) Nanocontamination d'organismes aquatiques par des particules inorganiques : transfert trophique et impacts toxiques Biodiversité et Ecologie. Université de Bordeaux

Praharaj S, Panigrahi S, Basu S, Pande S, Jana S, Ghosh SK, Pal T (2007) Effect of bromide and chloride ions for the dissolution of colloidal gold. J Photochem Photobiol A Chem 187:196-201

Renault S, Baudrimont M, Mesmer-Dudons N, Gonzalez P, Mornet S, Brisson A (2008) Impacts of gold nanoparticle exposure on two freshwater species: a phytoplanktonic alga (Scenedesmus subspicatus) and a benthic bivalve (Corbicula fluminea). Gold Bull 41:116-126

Tedesco S, Doyle H, Redmond G, Sheehan D (2008) Gold nanoparticles and oxidative stress in Mytilus edulis. Mar Environ Res 66:131-133

Teles M, Soares A, Tort L, Guimarães L, Oliveira M (2017) Linking cortisol response with gene expression in fish exposed to gold nanoparticles. Sci Total Environ 584:1004-1011

Volland M, Hampel M, Martos-Sitcha JA, Trombini C, MartínezRodríguez G, Blasco J (2015) Citrate gold nanoparticle exposure in the marine bivalve Ruditapes philippinarum: uptake, elimination and oxidative stress response. Environ Sci Pollut Res 22:17414 17424

Wang W-X (2013) Dietary toxicity of metals in aquatic animals: recent studies and perspectives. Chin Sci Bull 58:203-213 